Arch. Tierz., Dummerstorf 51 (2008) 5, 467-478

Institut für Tierzucht und Haustiergenetik der Justus Liebig Universität Giessen, Giessen, Germany

GUNHILD KURT and HORST R. BRANDT

\title{
Development and characterization of lambs' coats of East Prussian Skudden and Rough-coated Pomeranian Landrace sheep
}

\begin{abstract}
East-Prussian Skudden (Skudden) and Rough-coated Pomeranian Landrace (RPL) sheep are old endangered mixed-wool breeds. The fleece structure is unique for each breed compared with other characteristics in related breeds. Therefore, an essential factor in breed conservation is preservation of the typical fleece. As some RPL sheep show a tendency towards uniform fleeces, emphasis is placed on fleece evaluation in selection of flockbook ewes and especially in licensing rams. Currently, rams can only be presented at a minimum age of $1 \frac{1}{2}$ years when regrowth has sufficiently taken place. As these rare breeds are primarily kept in small flocks and not by shepherds, an earlier, preliminary selection for typical fleeces would aid in flock management.

Fleece samples were taken from five body regions at intervals of 30-35 days beginning at an age of one month to 8 months, prior to shearing and after regrowth. Adult samples were graded and those of RPL evaluated for type and colour. Fibre types were sorted and counted according to presumed adult type as well as lamb fibre type. An attempt was made to find a point in development suitable for concluding the final fibre type composition, taking into account the final grade, type and fleece colour.

In Skudden a preliminary selection is preferable at an age of 10-12 months. As RPL showed considerable changes in all fleece parameters between shearing and the adult sample, preliminary selection is not advisable.

Keywords: breed conservation, fleece evolution, lambs' coats, East-Prussian Skudden, Rough-coated Pomeranian Landrace
\end{abstract}

\section{Zusammenfassung}

Titel der Arbeit: Entwicklung und Charakterisierung der Lammvliese von Ostpreußischen Skudden und Rauhwolligen Pommerschen Landschafen

Ostpreußische Skudden (Skudde) und Rauhwollige Pommersche Landschafe (RPL) sind alte, vom Aussterben bedrohte Mischwollrassen. Die Zusammensetzung des Vlieses ist Kennzeichen der Rasse und unterscheidet sie - im Gegensatz zu anderen Merkmalen - von verwandten Rassen. Die Erhaltung der typischen Vliesstruktur ist ein wesentlicher Faktor in der Erhaltungszucht. Da einige RPL-Vliese eine Tendenz in Richtung Schlichtwolle aufweisen, ist die Bewertung des Vlieses entscheidend für die Selektion, insbesondere der Böcke. Bisher wurden Böcke erst in einem Alter von mindestens 1 1 1 Jahren zur Körung zugelassen, damit das Vlies nach der Schur genügend wieder aufwachsen konnte. Weil diese Rassen hauptsächlich in kleinen Herden und nicht von Berufsschäfern gehalten werden, wäre eine vorläufige Selektion nützlich.

Wollproben wurden an fünf Körperstellen in einem Entnahmerhythmus von 30-35 Tagen im Alter von 1-8 Monaten, vor der ersten Schur und nach dem Wiederaufwachsen entnommen. Adultproben wurden bewertet; bei RPL außerdem Vliestyp- sowie Farbe begutachtet. Fasertypen wurden zuerst nach vermutlichen Adult-, danach nach Lammfasertypen sortiert und ausgezählt. Es wurde versucht, einen geeigneten Zeitpunkt in der Entwicklung festzulegen, an dem Rückschlüsse über die endgültige Faserzusammensetzung, Bewertung, sowie Vliestyp- und Farbe sinnvoll sind.

Bei der Skudde ist eine vorläufige Selektion im Alter von 10-12 Monaten vorzuziehen. Da beim RPL in der Zeit zwischen der Schur und der Adultprobe alle Vliesparameter sich deutlich verändern, ist von einer früheren Selektion abzuraten.

Schlüsselwörter: bedrohte Rassen, Vlies-Evolution, Lammvliese, Ostpreußische Skudden, Rauhwollige Pommersche Landschafe 


\section{Introduction}

Breed conservation has become increasingly important since the end of the last century when dramatic loss of livestock diversity was recognized and monitoring as well as conservation measures were put in place by various organizations (DUCHEV and GROENEVELD, 2006). Status differentiation between a breed being "rare" in one country and it being endangered globally is am important criterion (DUCHEV, DISTL and GROENEVELD, 2006). A breeder's association for the two breeds of this study was formed in the 1980's to locate, register and select breeding stock with typical traits in order to preserve them with their original fleece structure. Strong emphasis was put on fleece composition as this characteristic is unique, allowing differentiation between related breeds.

Skudden were originally found in the Baltic region and belong to the short-tailed Northern Heath Group. Rams carry a throat fringe and are horned; ewes are mainly polled but scurs or small horns may occur. They are self-colour white, black or brown ie all fibre types have the same colour; wool fibres are not as strongly pigmented as kemp or heterotypes. The exceptions are the typical russet tinge and the black spots on the head and legs. Grey may occur in older sheep due to loss of pigmentation. Black fleeces often fade to russet. Lambs born russet (not brown) become white; a remainder of russet kemp may be found in these fleeces (STIEGER, 1888; KNABE et al., 1988; RASSEBESCHREIBUNG, 2008).

The RPL was originally indigenous to Pomerania and its islands. It is a medium sized landrace breed with a grey, blue-grey to blue fleece. Lambs are born black and obtain their final fleece colour due mainly to growth of wool fibres. Black eel-back and manes are original traits (FITZINGER, 1878; HERING, 1941; HEIDLER, 1955; RASSEBESCHREIBUNG, 2008).

Adult mixed-wool fleeces are composed of kemp (KH), heterotype (hairs) (LH) and true wool fibres (W). These fibre types are already present in wild sheep (CREW and BLYTH, 1923; KUN, 1996). The changes in fleece structure from wild sheep to mixed-wool and finally to uniform wool is defined as fleece evolution (RYDER, 1964; RYDER, 1983). The fleece of the Rough-coated Pomeranian Landrace (RPL) is a "missing link" (KURT-KUN, 1999).

Two intermediate fibre types can be found in some mixed-wool fleeces. They represent the transition from kemp to heterotype and from heterotype to wool fibre (KUN, 1996). Kempy heterotypes (kLH) grow continuously and are therefore found in the outer coat. They can be found in the Grey horned Heidschnucke, RPL and in the throat fringe of Skudden. Woolly heterotypes $(w L H)$ represent the final stage in the evolution of a uniform fleece.

The fleece of Skudden consists of kemp (15-250 $\mu$, Mean $68 \mu)$, heterotypes $(15-90 \mu$, Mean $44 \mu)$ and wool fibres $(7-40 \mu$, Mean $24 \mu)$. The LH are slightly waved. Wool fibres reach $60-100 \%$ of the total staple length, giving it a V-shape. Reduction in kemp content leads to coarsening of wool fibres. WLH are not typical. The throat fringe may contain $\mathrm{kLH}$. The fibre type ratio is $1 \mathrm{KH}: 2 \mathrm{LH}: 7 \mathrm{~W}$ (KUN, 1996).

KUN (1996) found two fleece types in the RPL. The original ("coarse") type represents a further step in fleece evolution. The majority (70-80\%) of kemp grow continuously ( $\mathrm{kLH} 25-102 \mu$, Mean $57 \mu$ ). These pigmented fibres build the outer

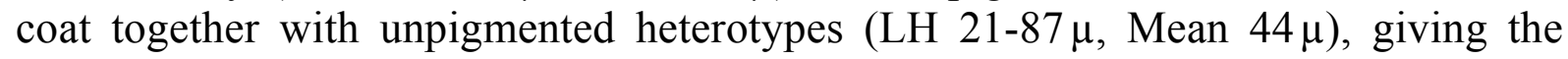
fleece its grey to blue colour. The remainder of kemp (KH 28-156 $\mu$, Mean $64 \mu$ ) 
undergo shedding. Wool fibres (W 13-55 $\mu$, Mean $31 \mu$ ) reach $80 \%$ of the total staple length, giving it a "block" form. The diameter range is greatly reduced compared to the Northern Heath group. The fibre type ratio is $1 \mathrm{KH}+\mathrm{kLH}: 2 \mathrm{LH}: 8 \mathrm{~W}$.

The second fleece type found in the RPL, the transitory ("fine") type, represents a "missing link" in the process of evolution from mixed-wool to uniform wool. The outer coat is soft to touch and consists of heterotypes (LH 29-85 $\mu$, Mean 52 $\mu$ ) and woolly heterotypes (wLH 24-73 $\mu$, Mean $30 \mu$ ), which replace kempy heterotypes and heterotypes, respectively. This leads to a reduction of pigmented fibres and often to a light grey fleece colour. The fibre type ratio is $1: 2.8: 5.9$ for $\mathrm{LH}: \mathrm{wLH}: \mathrm{W}$.

DRY (1975) describes 17 fibre types in lamb's coats and groups these in order of their appearance. RYDER (1965b) groups these fibres in three main categories by their order of appearance and fibre tip: pre-curly-tip, curly-tip and post-curly-tip.

RYDER and STEPHENSON (1968) describe the fibres types as follows:

1. Halo-hairs (Hh) belong to the pre-curly-tip group. They often protrude above the rest of the fibres giving the appearance of a halo.

2. Sickle-fibres possess a sickle-shaped tip. They are not medullated in the neck region. Super-sickle A (SSA) fibres however, are medullated throughout. SSA and SSB fibres have a break in the medulla at birth or in the neck, respectively. Fine sickle (Fine Sk) have no medulla in the post-natal region. Sickle fibres belong to the pre-curly-tip group.

3. Hairy-tip-Curly-tips ( $\mathrm{HtCt}$ ) belong to the Curly-tip group.

4. Curly-tips (CT) are non-medullated throughout or medullated only in the postnatal region.

5. Histerotrichs $(\mathrm{H})$ may be medullated (med. $\mathrm{H})$ in some breeds.

The goal of this investigation was to determine an age for preliminary selection for fleece structure, typical for the breed, based on characteristics in the lamb's coats. For this purpose the composition of fibre types in the adult fleece was compared to the lamb fibre types taken at different ages. Changes in the lambs' coats leading to a specific adult fleece composition must be traceable. Fibre types characteristic of the breed and decisive for final judgement must be brought into association with the grade, colour and fleece type to determine the feasible time for preliminary selection.

Materials and methods

Initially wool samples were taken from 53 Skudden and 35 RPL lambs born in the spring of 1997. The Skudden lambs, including 14 pairs of twins and one set of triplets, were offspring of 38 flockbook ewes from 14 flocks and eight licensed rams, one from Brandenburg. The RPL lambs, including 11 pairs of twins, were offspring of 24 flockbook ewes, 14 of which, as well as the ram were descendants of stock from the Island Rügen.

The final number of Skudden lambs with a complete set of samples was 36 (including 3 black lambs), giving a total of 1,435 wool samples. The final number of RPL lambs with complete samples was 17, giving a total of 765 wool samples.

Sampling occurred from the standard regions: shoulder, mid-side and britch. Additionally, in mixed wool breeds, a sample from the middle of the back provides information on the presence of the eel-back, a higher content of kemp and not necessarily defined by colour. A sample was also taken from the root of the tail, as this part of the body retains the original fleece structure most tenaciously during upgrading crosses (SPÖTTEL, 1925). 
Table 1

Age of lambs at sampling (days) (Alter der Lämmer bei Probenentnahme [Tage])

\begin{tabular}{lccc}
\hline \multicolumn{2}{l}{ Age Group, $\mathrm{n}=$ Skudden/RPL } & Skudden, $\mathrm{n}=36$ & RPL, $\mathrm{n}=17$ \\
\hline 1 & $15 / 15$ & $20-39$ & $17-39$ \\
2 & $21 / 5$ & $40-53$ & $40-54$ \\
3 & $24 / 17$ & $59-76$ & $55-78$ \\
4 & $24 / 16$ & $82-97$ & $79-99$ \\
6 & $23 / 16$ & $102-126$ & $100-126$ \\
8 & $19 / 12$ & $130-152$ & $130-153$ \\
10 & $25 / 9$ & $156-171$ & $156-177$ \\
11 & $23 / 17$ & $182-195$ & $180-201$ \\
12 & $40 / 10$ & $206-247$ & $210-221$ \\
& & $(274,281)$ & \\
Shearling & $36 / 17$ & $342-406$ & $371-396$ \\
& & $(331)(412)$ & $(307)(403)$ \\
Adult & $36 / 17$ & $563-702$ & $562-595$ \\
& & $(552,554)(758,767)$ & $(506)$ \\
\hline
\end{tabular}

( ) = individual exceptions

Each sampling of the five body parts took place in a defined marked region on the left side. The first sampling occurred at an age of 20-30 days. At this time the extent of halohair coverage was recorded. The first three samplings occurred in a cycle of $30 \pm 5$ days. Thereafter the cycle was $35 \pm 5$ days up to an age of eight months. The shearling sampling was taken 3 days prior to shearing at an age of 11-13 months. The last sampling (adult) occurred after the fleece had regrown sufficiently at an age of 18-25 months. The samples were grouped as in Table 1 for the purpose of statistical evaluation. Differentiation of fibre types and count occured using a light source with 2,700 Kelvin and 900 lumen (KUN, 1996). The specific reflection of each fibre type, especially the chalkiness of kemp, allows for a precise differentiation. Since colours appear differently under this light source, colour of fibre types and fleece were evaluated in day light. Otherwise grey, blue or brown would be classed as black.

The examined wool staples contained an average of 570 fibres. The fibres were sorted taking structure, crimp/wave and light reflection into consideration. At first they were classed based on their presumable adult fibre type. Unusual tips, thinning, extreme ribbon-like structures, as well as relative lengths in the complete staple were recorded. The fibres were then sorted by lamb fibre type.

The adult samples were graded ("excellent", "good" and "undesirable") and those of RPL additionally evaluated for fleece type ("coarse" or "fine") and colour ("light"

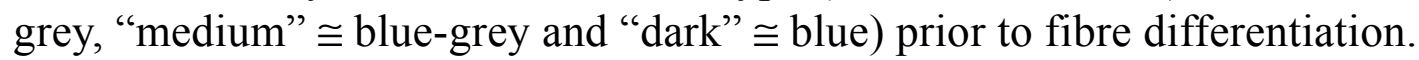

The investigation began with the adult samples and proceeded backwards to the first samples (birthcoat), so that development of a specific adult fleece structure may be traced. This sequence was chosen so that changes visible in the lamb may be used to predict the final fleece structure.

Examination of the RPL samples showed that $\mathrm{W}$ of a sample could be both pigmented and unpigmented. Additionally, unpigmented $\mathrm{W}$ with pigmented tips were found. Therefore RPL wool fibres were sorted based on pigmentation.

\section{Statistical analysis}

For the analysis of normal distributed traits, a variance analysis with the fixed effects breed, sex, body position and age group, using the GLM procedure of SAS version 8.1 was carried out. Traits not normally distributed were grouped into classes and differences between fixed effect classes were tested using chi square test statistics. 


\section{Results and Discussion}

\section{Halo-hair coverage}

The extent of halo-hair coverage in the birthcoat, used for selecting adult fleece type in the New Zealand Romney by DRY (1955 a-c) proved unsuitable for both breeds. All but two lambs had grade 6 (total coverage of halo-hairs). Woolly islands behind the elbow were not found. Two lambs, one RPL and one Skudden, had woolly islands on the neck and on the shoulder, respectively; they were therefore graded as grade 4 . These islands were no longer present in the adult, the samples of which were classed as "good". This parameter therefore does not provide a useful prediction of the final quality of the adult fleece.

\section{Successors of lamb fibre types}

Not all fibre types were observed in Skudden and RPL lambs. Pre-curly-tips found were: halo-hairs, sickle, SSA', SSB and fine Sk. The percentage of sickle fibres was generally low. However, these fibres were present in a significantly higher number of Skudden then RPL lambs. HtCts were found to form the curly "tips" visible to breeders. CTs were not found in the RPL and rare in Skudden. Medullated histerotrichs were found in both breeds.

Correlations of lamb fibre type to corresponding adult fibre type, as well as lamb fibre type and adult fibre type to adult fibre type in both shearling and adult fleeces were calculated for each age group. The correlations of shearling to adult fleece were also calculated (Tables 2 and 3). These results verify kemp (KH) as successor of halo-hair (Hh). Heterotypes primarily have $\mathrm{HtCt}$ as precursors. In Skudden $\mathrm{Hh}$ are partially replaced by heterotypes, instead of kemp. Sickle fibres are recognized as coarse, chalky heterotypes. Histerotrichs are clearly precursors of wool fibres. Medullated histerotrichs were found to be succeeded by woolly heterotypes (wLH) or by coarser wool fibres in RPL. In Skudden CTs as well as medullated histerotrichs were replaced by wLH.

Table 2

Correlations of Adult fibre types to Lamb fibre types

(Korrelationen der Adult Fasertypen zu Lammfasertypen für die Altersgruppen)

\begin{tabular}{|c|c|c|c|c|c|c|c|}
\hline \multirow[b]{2}{*}{ Age } & \multicolumn{4}{|c|}{ Skudden } & \multicolumn{3}{|c|}{ RPL } \\
\hline & $\mathrm{KH} / \mathrm{Hh}$ & $\mathrm{wLH} / \mathrm{mH}$ & $\mathrm{wLH} / \mathrm{CT}$ & $\mathrm{LH} / \mathrm{HtCt}$ & $\mathrm{KH} / \mathrm{Hh}$ & $\mathrm{wLH} / \mathrm{mH}$ & $\mathrm{LH} / \mathrm{HtCt}$ \\
\hline 1 & $0.980^{* * *}$ & $0.001^{\mathrm{ns}}$ & - & $0.889^{* * *}$ & $0.559^{* * *}$ & - & $0.132^{\mathrm{ns}}$ \\
\hline 2 & $0.733^{* * *}$ & $-0.269^{* *}$ & $0.033^{\mathrm{ns}}$ & $0.661^{* * *}$ & $0.522^{* *}$ & $0.370^{\mathrm{ns}}$ & $0.472^{\mathrm{ns}}$ \\
\hline 3 & $0.518^{* * *}$ & $-0.119^{\mathrm{ns}}$ & $0.242^{* *}$ & $0.691^{* * *}$ & $0.326^{* *}$ & $0.080^{\mathrm{ns}}$ & $0.477^{* * *}$ \\
\hline 4 & $0.337^{* * *}$ & $0.041^{\mathrm{ns}}$ & $0.274^{* *}$ & $0.591^{* * *}$ & $0.515^{* * *}$ & $0.572^{* * *}$ & $0.583^{* * *}$ \\
\hline 6 & $0.348^{* * *}$ & $-0.250^{* *}$ & $0.335^{* * *}$ & $0.551^{* * *}$ & $0.517^{* * *}$ & $0.380^{* * *}$ & $0.619^{* * *}$ \\
\hline 8 & $0.359^{* * *}$ & $0.005^{\mathrm{ns}}$ & $0.269^{* *}$ & $0.440^{* * *}$ & $0.664^{* * *}$ & $0.003^{\mathrm{ns}}$ & $0.153^{\mathrm{ns}}$ \\
\hline 10 & $0.357^{* * *}$ & $0.252^{* *}$ & $0.431^{* * *}$ & $0.518^{* * *}$ & $0.869^{* * *}$ & $0.609^{* * *}$ & $0.680^{* * *}$ \\
\hline 11 & $0.207^{*}$ & $0.202^{*}$ & $0.273^{* *}$ & $0.028^{* *}$ & $0.850^{* * *}$ & $0.242^{*}$ & $0.415^{* * *}$ \\
\hline 12 & $0.424^{* * *}$ & $0.509^{* * *}$ & $-0.035^{\mathrm{ns}}$ & $0.296^{* * *}$ & $0.833^{* * *}$ & $0.016^{\mathrm{ns}}$ & $0.172^{\mathrm{ns}}$ \\
\hline
\end{tabular}

Adult fibre types: $\mathrm{KH}=\mathrm{Kemp}$, wLH=woolly Heterotype, $\mathrm{LH}=$ Heterotype; Lamb fibre types: $\mathrm{Hh}=$ Halo-hair, $\mathrm{CT}=\mathrm{Curly}$ tip, $\mathrm{mH}=$ medullated Histerotrich; $\mathrm{ns}=$ not significant; ${ }^{*} \mathrm{p}<0.05,{ }^{* *} \mathrm{p}<0.01 ; * * * \mathrm{p}<0.001$

In Skudden a highly significant correlation of kemp to adult kemp was found for all age groups except 1and 3. From age group 10 to shearling the correlations to adult kemp were between 0.45 (age 12) and 0.53 (shearling). For wLH only age 6 was found to correlate significantly to adult content. For heterotypes all ages except 3,6 and 8 were found to be significant; high correlations to adult content were found 
from age $10 \mathrm{on}$. Based on the correlations of kemp to adult kemp, a judgement of kemp content and therefore of fleece grade is possible from age group 10 on. In RPL the only significant correlation calculated was shearling LH to adult LH.

Table 3

Correlations of Adult fibre types for all ages to adult content (Korrelationen der Adultfasertypen für alle Altersgruppen zu Adultgehalt)

\begin{tabular}{lcccrrr}
\hline Age & Kemp & $\begin{array}{c}\text { Skudden } \\
\text { Woolly } \\
\text { Heterotype }\end{array}$ & Heterotype & Kemp & $\begin{array}{c}\text { RPL } \\
\text { Heterotype }\end{array}$ & Heterotype \\
\hline 1 & $-0.012^{\text {ns }}$ & $0.034^{\text {ns }}$ & $0.380^{* * *}$ & $0.149^{\text {ns }}$ & - & $0.125^{\text {ns }}$ \\
2 & $0.339^{* * *}$ & $-0.011^{\text {ns }}$ & $0.319^{* * *}$ & $0.038^{\text {ns }}$ & $0.001^{\text {ns }}$ & $-0.101^{\text {ns }}$ \\
3 & $0.123^{\text {ns }}$ & $-0.101^{\text {ns }}$ & $0.128^{\text {ns }}$ & $0.073^{\text {ns }}$ & $-0.040^{\text {ns }}$ & $0.151^{\text {ns }}$ \\
4 & $0.282^{* *}$ & $-0.060^{\text {ns }}$ & $0.278^{* *}$ & $0.146^{\text {ns }}$ & $0.137^{\text {ns }}$ & $0.142^{\text {ns }}$ \\
6 & $0.297^{* *}$ & $-0.300^{* *}$ & $0.198^{*}$ & $0.178^{\text {ns }}$ & $0.110^{\text {ns }}$ & $0.147^{\text {ns }}$ \\
8 & $0.339^{* * *}$ & $-0.141^{\text {ns }}$ & $0.127^{\text {ns }}$ & $0.142^{\text {ns }}$ & $-0.045^{\text {ns }}$ & $-0.076^{\text {ns }}$ \\
10 & $0.463^{* * *}$ & $-0.140^{\text {ns }}$ & $0.577^{* * *}$ & $0.164^{\text {ns }}$ & $0.205^{\text {ns }}$ & $0.126^{\text {ns }}$ \\
11 & $0.502^{* * *}$ & $0.058^{\text {ns }}$ & $0.418^{* * *}$ & $0.061^{\text {ns }}$ & $0.109^{\text {ns }}$ & $0.221^{\text {ns }}$ \\
12 & $0.447^{* * *}$ & $0.005^{\text {ns }}$ & $0.382^{* * *}$ & $0.137^{\text {ns }}$ & $0.085^{\text {ns }}$ & $0.202^{\text {ns }}$ \\
Shearling & $0.530^{* * *}$ & $0.065^{\text {ns }}$ & $0.395^{* * *}$ & $0.142^{\text {ns }}$ & $0.051^{\text {ns }}$ & $0.385^{* *}$ \\
\hline
\end{tabular}

$\mathrm{ns}=$ not significant; ${ }^{*} \mathrm{p}<0.05,{ }^{*} \mathrm{p}<0.01 ; * * * \mathrm{p}<0.001$

\section{Per cent composition and fibre type ratio}

Per cent composition and fibre type ratios show the changes in development of fleece structure. The fibre type ratios also indicate the fibre type produced in the central und lateral primary follicles. High ( $>10 \%)$ kemp content (not due to shedding) indicates that the lateral primaries still produce this fibre type. On the other hand, a ratio of kemp: heterotypes greater than 1:2 indicates production of heterotypes also in the centrals.

Both percentages and fibre type ratios of adult fibre types were found to correspond to those in the adult from age 6 on in Skudden (Figure 1) and from age 8 on in RPL (Figure 2). The very high kemp content in the RPL was found to be due to shedding.

\section{Class, fleece type, fleece colour}

Evaluation of adult fleece classes result in differences in percentage of the most important fibre types. The point of differentiation may be suitable for selection.

The most important fibre type in grading Skudden and RPL fleeces is kemp. This fibre type, an original constituent in the fleece of both breeds, was reduced by crossing. As the goal is preservation of original fleece structure, kemp should be present in all body regions in the typical percentage in sheep selected as breeding stock. In Skudden wool fibres were found to be especially fine and "soft" when kemp was present. In RPL kemp is important for fleece colour; a reduction in content results in a light grey fleece colour. Additionally, the presence of $\mathrm{kLH}$ in the outer coat gives it the typical "rough" feel. An extreme reduction indicates production of heterotypes in some central primaries.

Woolly heterotypes are undesirable in adult Skudden. They are rarely found as remains of lamb fibres, as curly heterotypes. In RPL they are a sign of the "fine" transitory fleece type, in which true heterotypes have been replaced.

In Skudden significant differences in kemp content between adult classes were found for ages 3, 8, 12 and shearling. The wLH content between adult classes was significant for ages $4,6,10,11$ and 12. Based on these results, a point for selection 
including both fibre types could be ages 8, 12 and shearling. In the RPL the three classes varied in kemp content in all age groups except 4, 8 and 12. Significant differences in wLH content between adult classes were found for ages 4, 6, 10, 11 and 12. Therefore selection based on both fibre types could take place in age groups 6, 10 and 11 (Tables 4 and 5).

In the RPL evaluation of the two fleece types (Table 6) resulted in differences in kemp content for ages 1, 2, 10 and 11. Only age 12 varied in wLH content for the two fleece types.

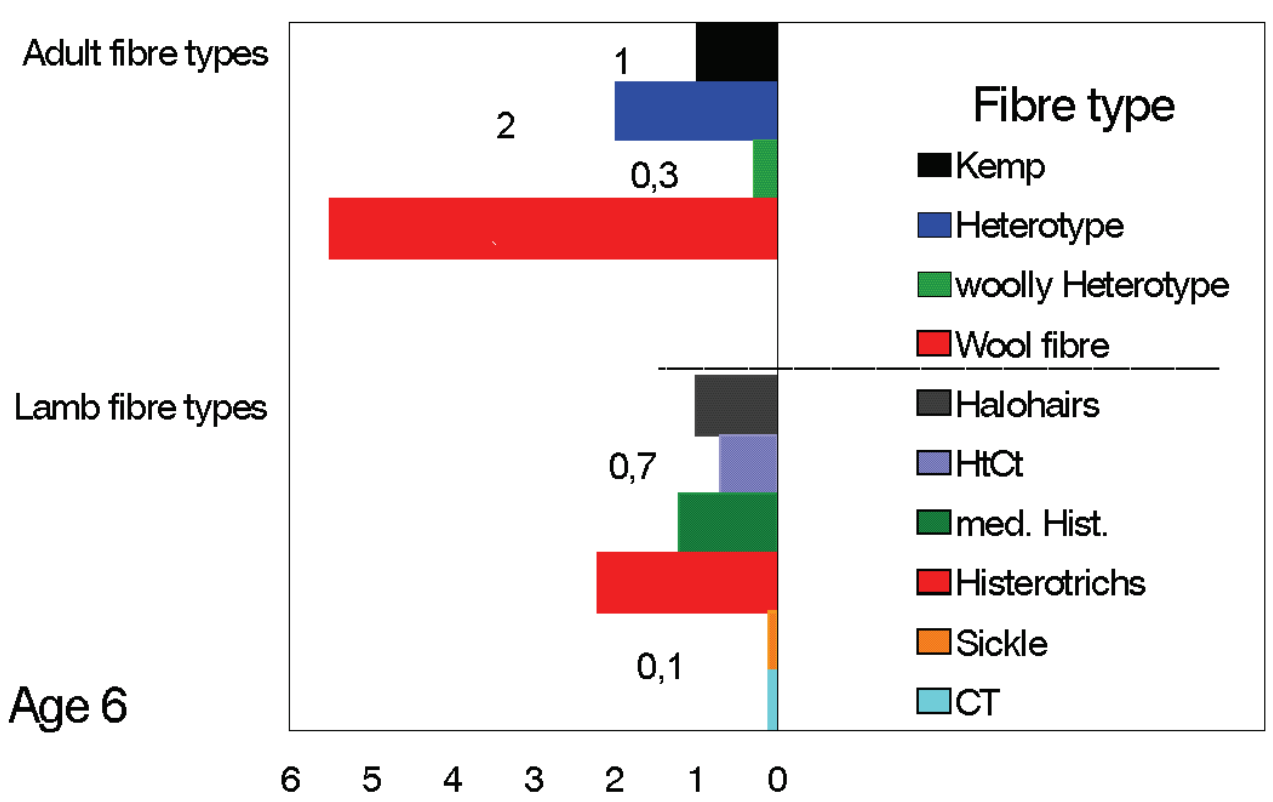

Fig. 1: Fibre type ratios of Skudden by adult and lamb fibre types at age 6 (Faserverhältnis nach Adult- und Lammfasertypen der Skudde [Alter 6])

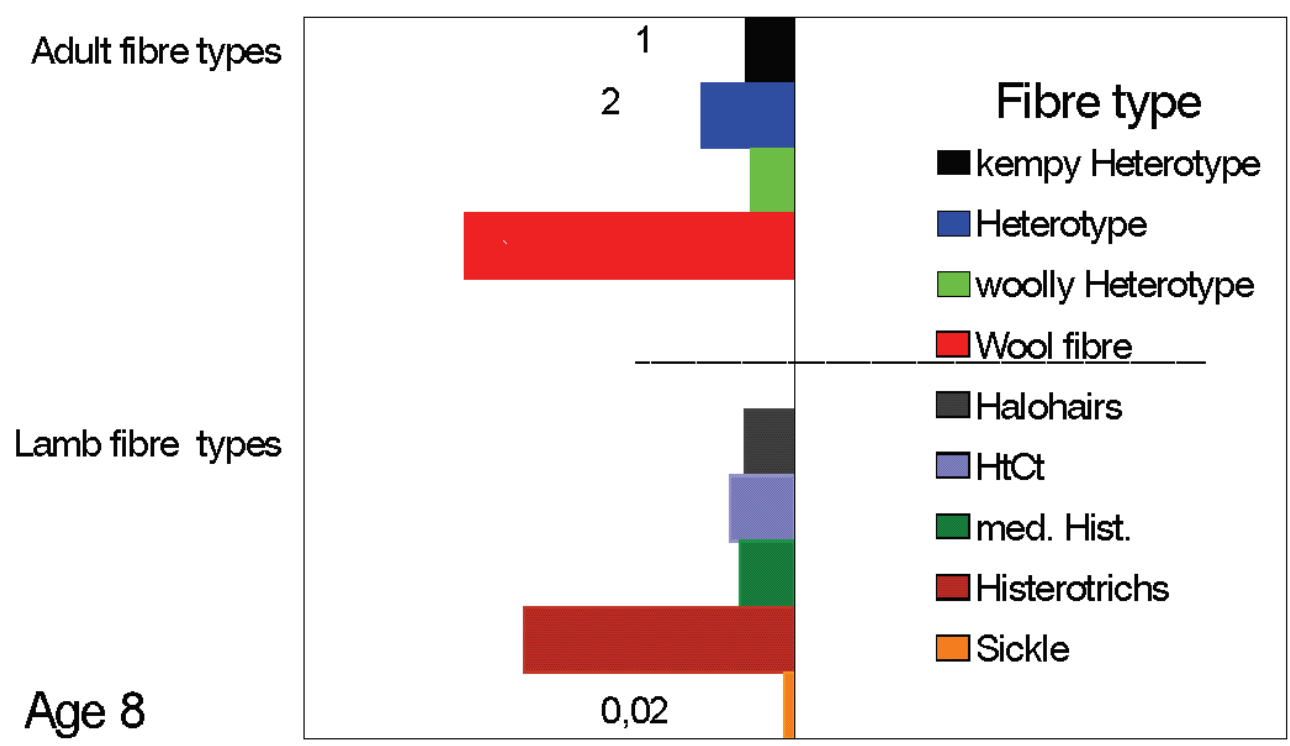

$\begin{array}{lllllllllll}10 & 9 & 8 & 7 & 6 & 5 & 4 & 3 & 2 & 1 & 0\end{array}$

Fig. 2: Fibre type ratios of RPL by adult and lamb fibre types at age 8

(Faserverhältnis nach Adult- und Lammfasertypen beim RPL [Alter 8]) 
Table 4

Mean per cent composition for classes in the adult fleece

(Durchschnittlicher Fasergehalt des Adultvlieses für die Bewertungsklassen)

\begin{tabular}{|c|c|c|c|c|c|c|}
\hline \multirow{2}{*}{$\begin{array}{l}\text { Race } \\
\text { Fibre type }\end{array}$} & \multicolumn{2}{|c|}{ Class1 (excellent) } & \multicolumn{2}{|c|}{ Class 2 (good) } & \multicolumn{2}{|c|}{ Class 3 (undesirable) } \\
\hline & $\%$ & $\mathrm{SD}$ & $\%$ & SD & $\%$ & $\mathrm{SD}$ \\
\hline \multicolumn{7}{|l|}{ Skudden, $n=180$} \\
\hline $\mathrm{Kemp}^{* * *}$ & 14.2 & 0.9 & 7.8 & 0.5 & 5.7 & 0.9 \\
\hline Woolly Heterotypes ${ }^{* *}$ & 6.8 & 0.9 & 6.8 & 0.6 & 3.6 & 1.1 \\
\hline Heterotypes $^{* * *}$ & 9.9 & 1.2 & 17.6 & 0.7 & 17.7 & 1.3 \\
\hline \multicolumn{7}{|l|}{$R P L, n=85$} \\
\hline $\mathrm{Kemp}^{* * *}$ & 33.3 & 3.2 & 27.7 & 1.8 & 19.8 & 2.8 \\
\hline Woolly Heterotypes** & 2.7 & 1.8 & 4.9 & 1.0 & 11.6 & 1.5 \\
\hline Heterotypes $^{* * *}$ & 7.3 & 3.3 & 14.3 & 1.8 & 18.2 & 2.9 \\
\hline
\end{tabular}

$* * \mathrm{p}<0.01 ; * * * \mathrm{p}<0.001$

Table 5

Significant differences in mean per cent composition for adult classes (\%/SD)

(Signifikante Unterschiede im Fasertypengehalt der Bewertungsklassen [(\%/SD])

\begin{tabular}{|c|c|c|c|c|c|c|}
\hline \multirow{2}{*}{$\begin{array}{l}\text { Fibre type } \\
\text { Age (n=Skudden/RPL) }\end{array}$} & \multicolumn{3}{|c|}{ Skudden } & \multicolumn{3}{|c|}{ RPL } \\
\hline & Class 1 & Class 2 & Class 3 & Class 1 & Class 2 & Class 3 \\
\hline \multicolumn{7}{|l|}{ Kemp } \\
\hline Age $6 \quad\left(115^{\mathrm{ns}} / 80^{*}\right)$ & $12.1 / 1.6$ & $10.1 / 0.8$ & $13.9 / 1.6$ & $13.3 / 1.8$ & $9.3 / 1.0$ & 7.6/1.6 \\
\hline Age $8 \quad\left(95^{*} / 60^{\mathrm{ns}}\right)$ & $13.2 / 1.3$ & $10.1 / 0.8$ & $7.9 / 1.5$ & $9.1 / 1.9$ & $10.0 / 0.9$ & $5.9 / 2.6$ \\
\hline Age $10\left(125^{\mathrm{ns}} / 45^{*}\right)$ & $13.2 / 1.0$ & $11.5 / 0.7$ & $9.9 / 1.3$ & - & $10.5 / 1.2$ & $5.4 / 2.5$ \\
\hline Age $11\left(115^{\mathrm{ns}} / 85^{* *}\right)$ & $14.2 / 1.3$ & $11.5 / 0.8$ & $10.1 / 1.3$ & $7.1 / 1.9$ & $10.4 / 1.0$ & $4.4 / 1.6$ \\
\hline Age $12\left(200^{* *} / 50^{\mathrm{ns}}\right)$ & $14.9 / 1.0$ & $11.3 / 0.7$ & $12.5 / 1.3$ & $9.2 / 1.5$ & $11.6 / 0.8$ & $7.5 / 2.1$ \\
\hline Shearling $(180 / 85)^{* * *}$ & $15.3 / 1.1$ & $10.0 / 0.7$ & $7.8 / 1.2$ & $8.4 / 3.4$ & $16.6 / 1.9$ & $4.8 / 2.9$ \\
\hline \multicolumn{7}{|l|}{ Woolly Heterotypes } \\
\hline Age $4 \quad\left(120^{* *} / 80^{*}\right)$ & $7.9 / 1.6$ & $2.0 / 1.1$ & $1.2 / 2.7$ & $26.6 / 4.2$ & $21.7 / 3.2$ & $13.7 / 2.9$ \\
\hline$\left(115^{\mathrm{ns}} / 80^{* *}\right)$ & $3.2 / 1.8$ & $3.0 / 1.0$ & $5.6 / 1.8$ & $-3.7 / 3.4$ & $4.8 / 1.9$ & $12.1 / 2.9$ \\
\hline Age $8 \quad\left(95^{*} / 60^{\text {ns }}\right)$ & $9.2 / 2.0$ & $3.3 / 1.2$ & $3.5 / 2.3$ & $6.2 / 2.9$ & $9.2 / 1.4$ & $6.1 / 4.1$ \\
\hline Age $10(125 / 45)^{* *}$ & $8.4 / 1.6$ & $4.4 / 1.0$ & $0.8 / 1.9$ & - & $3.9 / 1.4$ & $13.1 / 3.0$ \\
\hline Age $11\left(115^{* *} / 85^{* * *}\right)$ & $7.3 / 1.2$ & $2.5 / 0.8$ & $2.9 / 1.3$ & $17.2 / 2.3$ & $8.0 / 1.2$ & $6.4 / 1.9$ \\
\hline Age $12\left(200^{\mathrm{ns}} / 50^{*}\right)$ & $7.5 / 1.4$ & $5.8 / 0.9$ & $3.3 / 1.7$ & $17.0 / 2.6$ & $10.1 / 1.4$ & $7.6 / 3.7$ \\
\hline Shearling $\left(180^{* *} / 85^{* * *}\right)$ & $8.6 / 1.4$ & $9.7 / 0.9$ & $4.3 / 1.6$ & $18.7 / 3.9$ & $11.6 / 2.2$ & $9.4 / 3.4$ \\
\hline \multicolumn{7}{|l|}{ Heterotypes } \\
\hline Shearling $\left(180^{* *} / 85^{* * *}\right)$ & $14.2 / 1.7$ & $20.2 / 1.1$ & $19.0 / 2.0$ & $17.9 / 3.8$ & $9.1 / 2.1$ & $26.5 / 3.3$ \\
\hline
\end{tabular}

Class $1=$ excellent; class $2=$ good; class $3=$ undesirable; $n s=$ not significant; ${ }^{*} \mathrm{p}<0.05,{ }^{* *} \mathrm{p}<0.01 ;{ }^{* * *} \mathrm{p}<0.001$

Table 6

Mean per cent composition by fleece type and fleece colour $(\% / \mathrm{SD})$

(Durchschnittlicher Fasertypengehalt nach Vliestyp und Vliesfarbe [\%/SD))

\begin{tabular}{lccccc}
\hline $\begin{array}{l}\text { Fibre type } \\
\text { Age (n=RPL) }\end{array}$ & Type 1 (fine) & Type 2 (coarse) & Colour 1 (dark) & Colour 2 (medium) & Colour 3 (light) \\
\hline Kemp & & & & & \\
Age 1 $\left(74^{* * *} / 74^{* *}\right)$ & $14.5 / 2.5$ & $27.1 / 3.3$ & $14.9 / 2.1$ & $26.4 / 3.2$ & $21.1 / 4.7$ \\
Age 2 $\left(25^{* *} / 25^{\mathrm{ns}}\right)$ & $21.1 / 4.3$ & $6.1 / 2.7$ & $16.5 / 2.4$ & $18.4 / 5.4$ & $5.8 / 4.2$ \\
Age 10 $\left(45^{*} / 45^{* *}\right)$ & $7.5 / 1.4$ & $11.2 / 1.4$ & $8.9 / 1.1$ & $13.1 / 1.5$ & $6.0 / 2.2$ \\
Shearling $(85 / 85)^{\mathrm{ns}}$ & $13.7 / 1.5$ & $16.0 / 2.0$ & $14.4 / 1.6$ & $17.7 / 2.0$ & $12.4 / 2.9$ \\
Adult $\left(85^{\mathrm{ns}} / 85^{*}\right)$ & $17.7 / 1.6$ & $18.4 / 2.1$ & $22.3 / 1.7$ & $18.3 / 2.2$ & $13.4 / 3.1$ \\
Woolly Heterotypes & & & & & \\
Age 8 $\left(60^{\mathrm{ns}} / 60^{* *}\right)$ & $7.4 / 1.7$ & $10.8 / 2.2$ & $6.6 / 1.8$ & $4.9 / 2.2$ & $15.8 / 2.6$ \\
Age 12 $(85 / 50)^{* * *}$ & $9.4 / 1.0$ & $19.5 / 1.5$ & $8.0 / 1.1$ & $11.4 / 1.5$ & $24.0 / 2.0$ \\
Shearling $\left(85^{\mathrm{ns}} / 85^{*}\right)$ & $9.2 / 1.6$ & $14.2 / 4.1$ & $7.4 / 1.7$ & $10.4 / 2.1$ & $17.4 / 3.1$ \\
Adult $\left(85^{* * *} / 85^{\mathrm{ns}}\right)$ & $7.7 / 0.7$ & $1.1 / 1.0$ & $5.3 / 0.8$ & $3.3 / 1.0$ & $4.7 / 1.4$ \\
\hline
\end{tabular}

$\mathrm{ns}=$ not significant ${ }^{*} \mathrm{p}<0.05, * * \mathrm{p}<0.01 ; * * * \mathrm{p}<0.001$ 
In the RPL kemp is pigmented and therefore responsible for the fleece colour since heterotypes are mainly unpigmented. Comparison of the kemp content for the three fleece colours in the RPL (Table 6) showed significant differences for ages 1 and 10. The wLH content of the three fleece colours varied for ages 8, 12 and shearling.

Age 10 was found to be significant for kemp content for all three parameters: class, fleece type and fleece colour. Differences in wLH content were found in age 12 for type and ages 12 and shearling for class and colour. A preliminary selection should primarily be based on kemp, as this fibre type can be clearly recognized and its content estimated directly on the lamb.

With the exception of a few russet kemp in the fleece of white sheep, kemp content does not influence fleece colour in Skudden as this breed is self-colour ie all fibre types (including wool fibres) have the same colour.

\section{Pigmentation of wool fibres}

Wool fibre with pigmented tips were discovered in the RPL. These fibres were rare and mainly present for a short time span. Changes in percentage composition of the three types of wool fibres were significant. Possible correlations to fleece type and colour could aid selection

In the evaluation of fleece type significant differences were found in the percentages of all three wool fibre colours. In the "coarse" RPL the percentage of wool fibres with pigmented tips was clearly higher between ages 3 and 4 . Whereas the content decreased in the "fine" type, a second peak was found at shearing in the "coarse" type. The percentage of pigmented wool fibres is higher in the "fine" type and constant at circa $80 \%$. In the "coarse" type an increase between age 1 and 2 can be found. The content of unpigmented wool fibres rises more slowly in the "fine" type. In the evaluation of fleece colour (Figure 3) significant differences were found for pigmented and unpigmented wool fibres. Wool fibres with pigmented tips reached a peak at age 3 in the colours "dark" and "medium" and at age 4 in the colour "light". The fibres with pigmented tips can thereafter be disregarded in the colours "dark" and "light". In the fleece colour "medium", however a second peak occurs at shearing. The increase in unpigmented wool fibres from age 4 on corresponds to the decrease in pigmented fibres. The three fleece colours differ from age 10 on with regard to pigmented wool fibres. The rise in this colour occurs between ages 10 and 11 for "light" and between ages 11 and 12 for "dark" fleeces. In "light" fleeces the percentage of pigmented and unpigmented fibres is approximately equal between age 12 and shearing. In "medium" fleeces both lines cross at circa $40 \%$ at shearing.

The results in RPL can be summarized as follows: Fleece type "coarse" as well as fleece colour "medium" have a high percentage of wool fibres with pigmented tips at age 3 and a second peak at shearing ( $\cong 15 \%)$. These changes in composition of wool fibre colour are difficult to observe in the lamb.

\section{Preliminary selection}

Low but utilizable heritabilities in "wool quality", based on the undefined grade given at flockbook registration for sheep already preselected as suitable for breeding stock, were found by DE VRIES et al. (2003) in several landrace breeds. 

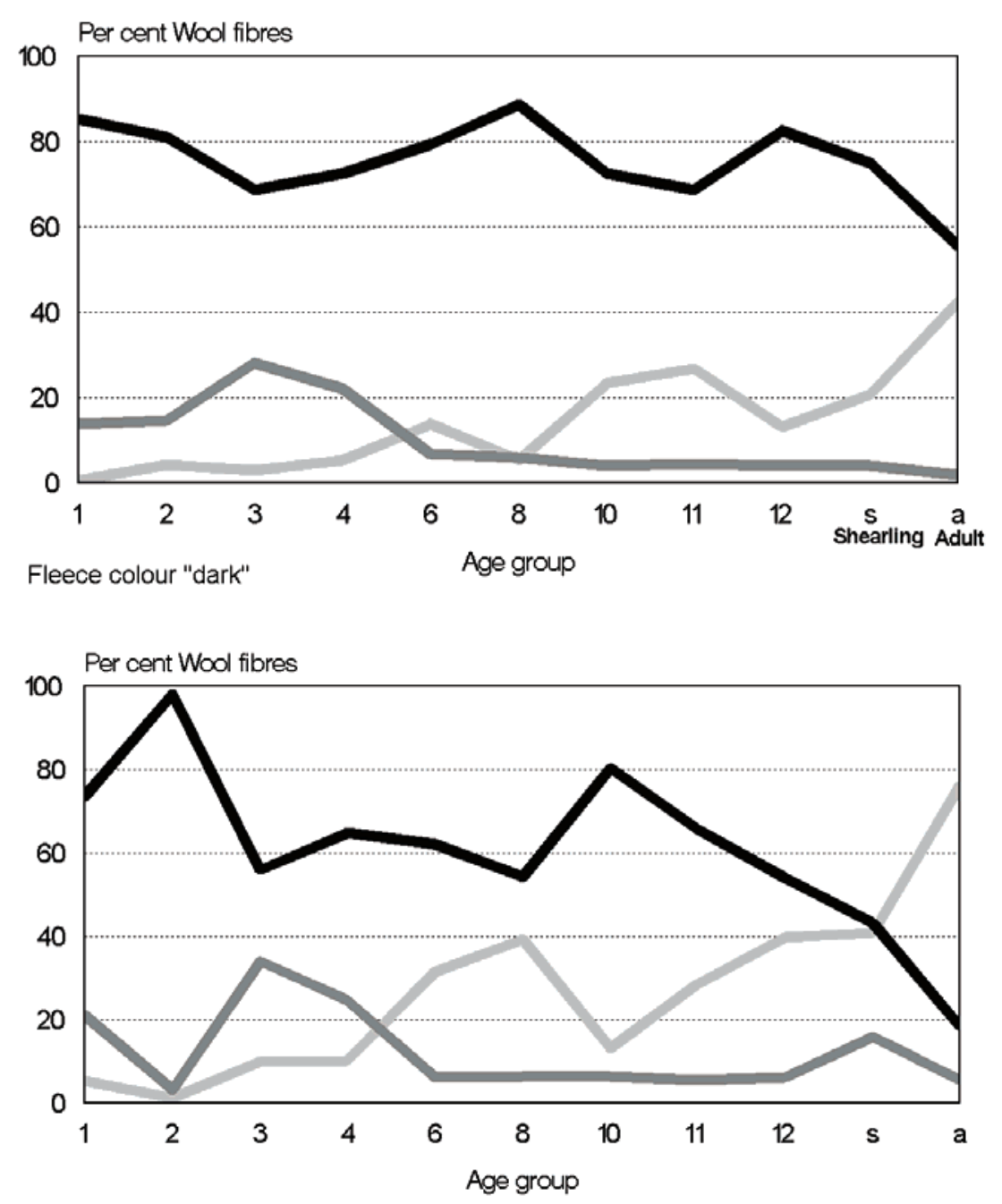

Fleece colour "medium"

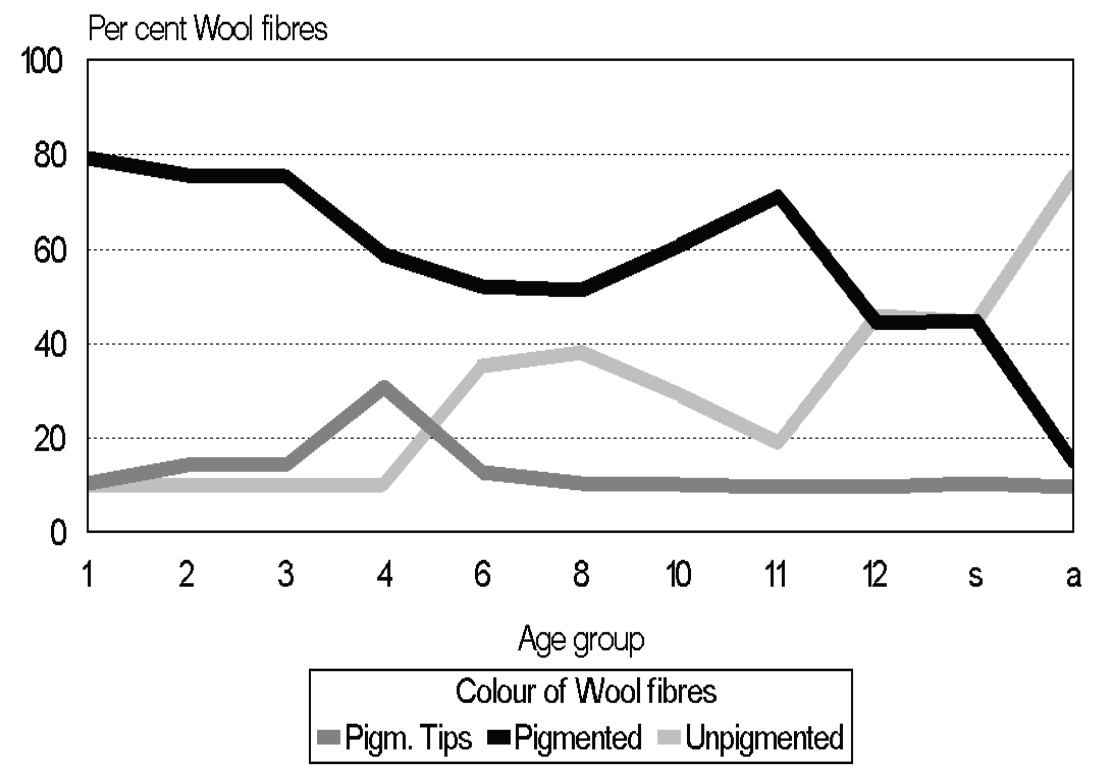

Fleece colour "light"

Fig. 3: Per centage of Wool fibre Colours for Adult Fleece Colours in RPL (Gehalt der Wollfaserfarben für Adult Vliesfarben beim RPL) 
The time of preliminary selection should summarize as many of the evaluated relationships as possible. For Skudden selection based on per cent composition and fibre type ratio is possible from age 6 (3-4 months) on. From age 8 (4-5 months) on, the differentiation in kemp and wLH content of the adult classes provides additional information. From age 10 (6 months) on a high correlation of kemp to adult kemp was found. Additionally, class differences in kemp and wLH content were found at age 12 (7 months) and at shearing. Selection at age 10 or 12 (7-8 months) is preferable to shearing as the fleece generally presents itself better before winter.

In RPL the parameters fleece type and colour must additionally be considered. Selection based on percentage composition and fibre type ratio is possible from age 8 (4-5 months) onwards. Differentiation in kemp and wLH content of the classes takes place at ages 10-11. For fleece type this differentiation occurs at ages 10-11 and 12 with regard to kemp and wLH content, respectively. Age 10 proved suitable for predicting fleece colour based on kemp. Differences in wLH content of the three fleece colours are found at ages 8,12 and shearing. Shearling fleeces are not suitable as considerable changes in kemp and wLH content occur between shearing and the adult sample. These two fibre types are decisive in judging class, type and colour. As kemp content is easier to estimate, selection should initially be based on this fibre type. Samples from lambs with low kemp content should then be examined for wLH. As considerable changes take place after shearing, only the regrowth (adult) sample is suitable for these evaluations.

\section{Acknowledgements}

We would like to thank the Ostpreußische Landgesellschaft $m b H$ and the Pommersche Landgesellschaft $\mathrm{mbH}$ for their financial support.

\section{References}

CREW, F.A.E. and BLYTH, J.S.S.:

On Fibres of Intermediate Character found in the Fleece of Ovis Vignei. Ann. Appl. Biol. 10 (1923), 295-300

DE VRIES, F.; HAMANN, H.; DISTL, O.:

Schätzung genetischer Parameter für Landschafrassen. Arch. Tierz. 47 (2003), 351-358

DRY, F.W. (1955 a-c): DRY, F.W.: cited by RYDER, M.L. and STEPHENSON, S.K.: Wool Growth. London, New York (1968), 352-354

The Architecture of Lambs' Coats: A Speculative Study. Palmerston North, Neuseeland, Massey University (1975)

DUCHEV, Z.; GROENEVELD, E.: Improving the monitoring of animal genetic resources on National and International level. Arch. Tierz. 49 (2006), 532-544

DUCHEV, Z.; DISTL, O.; GROENEVELD, E.:

Early warning system for loss of diversity in European livestock breeds. Arch. Tierz. 49 (2006), 521531

FITZINGER, L.J.:

Ueber die Racen des zahmen Schafes. Wien, Sitzungsb. d. k.k. Akad. d. Wiss. Mathem.-Naturwiss. Classe, 38. Bd. 141-222, 343-412, 39. Bd. 767-836, 41. Bd. 151-246. (1859/60)

HEIDLER, G.:

Das rauhwollige Landschaf und seine Leistungen im Zuchtgebiet Mecklenburg. Univ. Rostock, Ldw. Fak., Diss. Agr. (1955) 
HERING, K.:

Landesverband Pommersche Schafzüchter e.V. Stettin, in: DOEHNER, H. (Hrsg.): Handbuch der Schafzucht und Schafhaltung, 2. Bd., 1. Teil: Die Deutschen Stammzuchten und Zuchtgebiete. Berlin, Paul Parey (1941)

KNABE, P; FISCHER, A.; LEUCHT, W.:

KUN, G.:

Die Skudde - eine Rassenstudie. Arch. Tierz. 31 (1988), 83-90

Beiträge zur Charakterisierung und Verwendung der Mischwollen von Ostpreußischen Skudden und Rauhwolligen Pommerschen Landschafen. Giessen, Liebig Univ., Diss. Vet. (1995): 1. Aufl. Aachen, (1996)

KURT-KUN, G.:

Discourses on the Characterization and the Use of the Mixed Wools of East- Prussian Skudden and Rough-coated Pomeranian Landrace. 1. geänd. Aufl., zweispr. Aachen (1999)

RASSEBESCHREIBUNG:

in: Zuchtbuchordnung und Satzung des Zuchtverbandes für Ostpreußische Skudden und Rauhwollige RYDER, M.L.: Pommersche Landschafe in der Fassung vom 8.3.2008. (2008)

RYDER. M.L. (1965b):

RYDER, M.L.:

cited by RYDER, M.L. and STEPHENSON, S.K.: Wool Growth. London, New York (1968), 326-329

Sheep and Man. London (1983)

RYDER, M.L. and STEPHENSON, S.K.:

Wool Growth. London, New York (1968)

SAS INSTITUTE:

SAS/ STAT Users Guide, Version 8.1. Cary, NC, USA (2002)

SPÖTTEL, W.:

Über Variabilität, korrelative Beziehung und Vererbung der Haarfeinheit bei Schafen. Leipzig (1925)

STIEGER, G.:

Studien zur Monographie der Heidschnucke. J. f. Landwirt. XXVI, (1888), 139-247

Received: 2008-03-04

Accepted: 2008-08-19

\author{
Authors: \\ Dr. GUNHILD KURT* \\ Im Frankfurter Grund 12 \\ 63073 Offenbach-Bieber \\ Germany
}

apl. Prof.Dr. HORST R. BRANDT

Institut für Tierzucht und Haustiergenetik

Justus Liebig Universität Gießen

Ludwigstraße $21 \mathrm{~B}$

35390 Gießen

Germany

*Corresponding author

email: kurt-bieber@t-online.de 